\title{
TRADISI “UANG SIRIAH” DALAM TIMBANG TANDO DI NAGARI LANGSAT KADAP KECAMATAN RAO SELATAN KABUPATEN PASAMAN DITINJAU DARI 'URF
}

\author{
Sri Mawiyah', Afrian Raus ${ }^{2}$ \\ ${ }^{1}$ Institut Agama Islam Negeri (IAIN) Batusangkar \\ e-mail: mawiyahsri12@gmail.com \\ 2 Institut Agama Islam Negeri (IAIN) Batusangkar \\ e-mail: afrian.raus@yahoo.com
}

\begin{abstract}
Studi ini mengkaji tentang Tradisi "Uang Siriab" dalam timbang tando di Nagari Langsat Kadap Kecamatan Rao Selatan Kabupaten Pasaman ditinjau dari 'urf. Dari permasalaban tersebut muncul pertanyaan bagaimana proses pelaksanaan Uang Siriah dalam timbang tando di Nagari Langsat Kadap Kecamatan Rao Selatan Kabupaten Pasaman dan bagaimana tinjauan 'Urf terhadap pelaksanaan Uang Siriah. Jenis penelitian yang penulis gunakan adalah jenis penelitian lapangan (field research), untuk mendapatkan data-data dari permasalahan yang diteliti menggunakan metode kualitatif. Hasil penelitian yang penulis temukan bahwa sebelum melaksanakan perkawinan ada aturan adat yang harus dijalankan di Nagari Langsat Kadap Kecamatan Rao Selatan Kabupaten Pasaman yaitu calon laki- laki harus membayar uang siriah kepada niniak mamak pibak perempuan dalam proses timbang tando. Pelaksanaan uang siriah dalam pertunangan pada masyarakat Nagari Langsat Kadap pertama diawali proses monyuruah (menyampaikan kehendak). Kedua, proses timbang tando, setelah acara tukar menukar selesai maka dilanjutkan pemberian uang siriah oleh pibak laki- laki kepada niniak mamak perempuan berjumlab R. 600. 000. Sanksi bagi yang melanggar diakibatkan terjadi penundaan perkawinan yang sudah ditetapkan oleh kesepakatan bersama niniak mamak di Nagari Langsat Kadap. Tinjauan 'urf terbadap keberadaan uang siriah dalam timbang tando adalab termasuk kepada golongan Urf Shabih, hal ini berdasarkan syarat-syarat Urf dijadikan sebagai sumber hukum Islam yaitu, adat tersebut bernilai maslahat karena berdampak baik kepada pibak keluarga lakilaki dan pibak keluarga perempuan. Dengan adanya uang siriab ini memperlibatkan keseriusan seorang laki-laki menikahi seorang perempuan, memperlihatkan tanggung jawab laki-laki, terjailnnya silaturahmi dengan niniak mamak. Bagi keluarga yang keberatan atau tidak mampu seharusnya ditanggung bersama oleh niniak mamak pibake laki- laki sebagai ta'aun atau tolong menolong, supaya tidak mendapat sanksi dan penundaan perkawinan.
\end{abstract}

Kata kunci: Tradisi, Uang Siriah, Timbang Tando, Urf.

\section{PENDAHULUAN}

$\boldsymbol{B}$ erpasang-pasang merupakan salah satu sunatullah atas seluruh makhluk-Nya, baik manusia, hewan maupun tumbuh-tumbuhan. Allah swt berfirman: 


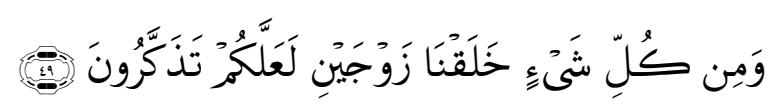

"Dan segala sesuatu kami ciptakan berpasang-pasangan supaya kamu mengingat kebesaran Allah".(Adz-Dzaariyaat:49)

Perkawinan menurut hukum Islam adalah pernikahan, yaitu aqad yang yang sangat kuat atau mitsaqan gholidhan untuk mentaati perintah Allah dan melaksanakannya merupakan ibadah. (Kompilasi Hukum Islam, Pasal 2: 19)

Laki-laki dan perempuan dijadikan berhubungan dan saling melengkapi dalam rangka melanjutkan keturunan yang banyak, sebagaimana yang dijelaskan dalam firman Allah surat an- Nisa' ayat 1. (Elimartati, 2013: 3)

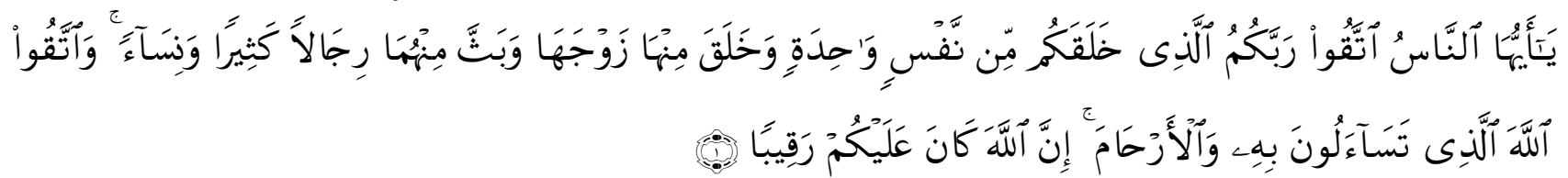

"Hai sekalian manusia, bertakwalah kepada Tuhan-mu yang telah menciptakan kamu dari seorang diri, dan dari padanya Allah menciptakan isterinya; dan dari pada keduanya Allah memperkembang biakkan laki-laki dan perempuan yang banyak. dan bertakwalah kepada Allah yang dengan (mempergunakan) nama-Nya kamu saling meminta satu sama lain dan (peliharalah) hubungan silaturrahim. Sesungguhnya Allah selalu menjaga dan mengawasi kamu". (Q.S AnNisa':1)

Sebelum melangsungkan perkawinan biasanya masyarakat melakukan khitbah atau peminangan. Oleh karena itu, syariat islam menghendaki pelaksanaan pranikah (peminangan) untuk menyingkap kecintaan kedua pasang manusia yang akan mengadakan transaksi nikah, agar dapat membangun keluarga yang didasarkan kepada kecintaan yang mendalam. (Abdul Aziz Muhammad Azzam dan Abdul Wahhab Sayyed Hawwas, 2011:7)

Perkawinan itu memiliki rukun dan syarat, yang mana rukun dan syarat perkawinan itu sebagai berikut:

a. Rukun perkawinan adalah sebagai berikut:

Menurut Jumhur ulama rukun perkawinan itu terdiri atas :

1. Adanya calon suami yang akan melakukan pernikahan;

2. Adanya calon istri yang akan melakukan pernikahan;

3. Adanya wali;

4. Adanya dua orang saksi;

5. Sighat akad nikah.

b. Syarat perkawinan adalah sebagai berikut:

1. Calon suami

a) Beragama Islam;

b) Laki-laki;

c) Jelas orangnya;

d) Dapat memberikan persetujuan;

e) Tidak terdapat halangan perkawinan.

f) Calon isteri

g) Beragama, meskipun Yahudi maupun Nasrani; 
h) Perempuan;

i) Jelas orangnya;

j) Dapat memberikan persetujuan;

k) Tidak terdapat halangan perkawinan.

2. Wali nikah

a) Laki-laki;

b) Dewasa;

c) Mempunyai hak perwalian;

d) Tidak terdapat halangan perwaliannya.

3. Saksi nikah

a) Minimal dua orang laki-laki;

b) Hadir dalam ijab qabul;

c) Dapat mengerti maksud akad;

d) Islam;

e) Dewasa;

f) Ijab qabul;

g) Adanya pernyataan mengawinkan dari wali;

h) Adanya pernyataan penerimaan dari calon mempelai;

i) Memakai kata-kata nikah, tazwij atau terjemahan dari kedua kata tersebut;

j) Antara ijab dan qabul bersambungan;

k) Antara ijab dan qabul jelas maksudnya;

1) Orang yang terkaid dengan ijab dan qabul tidak sedang ihram haji atau umrah;

m) Majlis ijab dan qabul itu harus dihadiri minimum empat orang yaitu calon mempelai atau wakilnya, wali dari mempelai wanita dan dua orang saksi. (Amiur Nuruddin dan Azhari Akmal Tarigan, 2004: 62-63)

Rukun dan syarat-syarat perkawinan tersebut di atas wajib dipenuhi, apabila tidak terpenuhi maka perkawinan yang dilangsungkan tidak sah. (Ahmad Rofiq, 2013: 55-56). Berdasarkan survei awal yang penulis lakukan di Nagari Langsat Kadap Kecamatan Rao Selatan Kabupaten Pasaman ketika seseorang akan melangsungkan perkawinan ada halhal dan ketentuan adat yang yang harus dilakukan diantaranya yaitu Monyuruah atau mengantar kata, Timbang Tando dan Qonuri.

Monyuruah merupakan ketentuan adat di Nagari Langsat Kadap Kecamatan Rao Selatan Kabupaten Pasaman yang maksudnya pihak keluarga laki-laki yang terdiri dari orang tua calon mempelai beserta Niniak Mamak yang melakukan pertemuan di rumah perempuan yang dihadiri oleh calon mempelai dan orang tua mempelai. Pertemuan tersebut merupakan pertemuan awal untuk kedua belah pihak keluarga yang isinya pernyataan maksud dari pihak calon laki-laki untuk mempersunting calon si perempuan. Pada pertemuan itu juga diketahui hasil setuju atau tidak setuju si perempuan. ketika maksud itu diterima dari perempuan. Maka, akan ditentukan hari hari timbang tando atau peminangan. (Antoni, niniak mamak, wawancara pribadi, 30/12/2019 Pukul 08.00)

Sebelum melangsungkan perkawinan masyarakat melakukan khitbah atau peminangan, masyarakat di Nagari Langsat Kadap Kecamatan Rao Selatan Kabupaten 
Pasaman menyebutnya dengan Timbang Tando, setiap daerah berbeda-beda dalam melakukan khitbah. Prosesi timbang tando dilakukan pada malam hari yang sudah ditentukan sebelumnya, dimana pihak laki-laki yang terdiri dari laki-laki atau calon, orang tua calon mempelai, datuak beserta niniak mamak bertemu mengadakan di rumah calon mempelai perempuan pada malam hari. Isi dari pertemuan itu adalah pemberian tando berupa kain sarung dari pihak laki-laki dan kain panjang dari pihak perempuan sebagai bukti persetujuan akan dilangsungkan perkawinan. Kedua calon mempelai mengikat janji Dengan istilah adatnya kok duduak indo ke bokisar, kok togak indo ke bopaliang, artinya lah baikek kayu jo tali kok lah boikek janji jo kato. Jadi, maskudnya apabila sudah diadakan pertunangan antara laki-laki dan perempuan maka keduanya sudah terikat dalam pertunangan atau perjanjian. (Antoni, niniak mamak, wawancara pribadi, 30/12/2019 Pukul 08.00)

Dalam pertemuan itu juga diberikan uang siriah (jumlahnya sudah ditentukan oleh adat) oleh pihak laki-laki. Uang siriah merupakan syarat perkawinan bisa dilangsungkan. Dengan kata lain, apabila uang siriah tidak dibayar maka akan mengakibatkan tertundanya perkawinan. Uang siriah ini sebanyak Rp. 600.000 dan ini berlaku untuk siapa saja, uang siriah tersebut tujuannya untuk niniak mamak calon pengantin perempuan. Orang-orang yang akan mendapatkan yaitu niniak mamak, imam qotik, tongku, ketua sumando. Ketentuan adat ini sudah dilakukan semenjak dahulu.

Uang siriah tidak memandang siapapun yang akan melaksanakan perkawinan baik itu bujang maupun duda. Adat pemberian uang siriah dipertahankan keberadaannya oleh masyarakat nagari Langsat Kadap Kecamatan Rao Selatan Kabupaten Pasaman karena sudah ada sejak nenek moyang dan sudah melekat sebagai keharusan dalam adat perkawinan nagari Langsat Kadap. (Sakmar datuak bandaharo, ketua KAN, wawancara pribadi /12/2019 pukul 14.00 WIB.

Aturan uang siriah tersebut sudah dilaksanakan sejak dahulu dan turun temurun sampai saat ini. Yang menetapkan aturan ini adalah niniak mamak terdahulu yang disepakati di Nagari Langsat Kadap Kecamatan Rao Selatan Kabupaten Pasaman. Alasan dari diberlakukannya aturan tersebut dengan tujuan agar orang yang akan menikah dengan mengikat dirinya dalam ikatan pertunangan tidak main-main lagi atau sebagai bukti awal bahwa mereka akan melangsungkan pernikahan. (Burhan Rajo Nen Adel (adil), wawancara pribadi, 19/02/2020 pukul 10.00 WIB)

Tabel 1. 1 Berikut data-data pelaku peminangan

\begin{tabular}{|c|c|c|c|}
\hline No & \multicolumn{2}{|c|}{ Nama pasangan } & Tahun Timbang Tando \\
\hline 1. & Didi & Reka & 2018 \\
\hline 2. & Ivo & Lisa & 2018 \\
\hline 3. & Ihsan & Nita & 2019 \\
\hline 4. & Fahri & Ria & 2019 \\
\hline
\end{tabular}


Dari tabel di atas dapat dipahami bahwa orang-orang tersebut tidak membayar uang siriah dan perkawinanya tidak bisa dilaksanakan. Tidak bisa dilaksanakan ini maksudnya adalah uang siriah ini bersifat sementara, maksudnya perkawinan ini dapat dilangsungkan apabila uang siriah ini telah dibayarkan. Hal ini seperti yang dialami oleh Ihsan dan Nita yang telah terjadi kesepakatan uang siriah pada bulan 02, Februari, 2019. Namun ketika itu tidak bisa dibayar, Maka perkawinan antara ihsan dan Nita ditunda sementara sampai Ihsan dapat membayar Uang Siriah kepada niniak mamak pihak perempuan. Namun pada 12 Maret 2019 Ihsan membayarkan uang siriah tersebut sehingga ia dapat melangsungkan perkawinannya dengan Nita, dari tabel di atas juga ada yang batal menikah dengan pasangan tersebut dan menikah dengan orang lain tentunya setelah membayar uang siriah. (Antoni, niniak mamak, wawancara pribadi, 20/02/2020 Pukul 08.00).

\section{METODE PENELITIAN}

Penelitian ini adalah penelitian lapangan (Fiel Research), Setelah data terkumpul setelah data terkumpul melalui observasi dan wawancara kemudian diolah dengan metode triagulasi kemudian dianalisis secara kualitatif dan dinarasikan secara efektif sehingga dapat menjawab permasalahan yang diteliti.

\section{HASIL DAN PEMBAHASAN}

Setiap masyarakat adat Nagari Langsat Kadap Kecamatan Rao Selatan Kabupaten Pasaman diawali terlebih dahulu dengan timbang tando secara adat. diawali dengan timbang tando guna memberikan kesempatan kepada kedua belah pihak terutama pihak perempuan untuk mempersiapkan segala sesuatu yang berkaitan dengan pernikahan seperti persiapan dana mendo'a, ataupun pesta.

Uang siriah dalam timbang tando merupakan salah satu prosesi perkawinan di Nagari Langsat Kadap Kecamatan Rao Selatan Kabupaten Pasaman. Uang siriah merupakan uang yang diberikan oleh pihak laki- laki kepada niniak mamak pihak perempuan dalam timbang tando selain dari mahar sebesar Rp. 600.000. (Sakmar Datuak Bandaharo, Ketua Adat, Wawancara pribadi, 23/ 02/ 2010 pukul: 10.00 WIB)

Kewajiban pemberian uang siriah ini juga disampaikan oleh salah satu niniak mamak di Nagari Langsat Kadap Kecamatan Rao Selatan Kabupaten Pasaman ia berpendapat bahwa uang siriah yaitu "uang yang diberikan oleh calon laki- laki kepada niniak mamak calon perempuan sebagai pemberian ketika akan melaksanakan perkawinan dalam timbang tando pada malam hari".

Berdasarkan penjelasan diatas pada dasarnya uang siriah disiapkan oleh calon mempelai pria dan diberikan kepada niniak mamak calon mempelai wanita yang sudah ditetapkan semenjak dahulu yaitu sebesar Rp. 600. 000.

Sejarah diberlakukan uang siriah ini diperjelaskan oleh salah satu niniak mamak di Nagari Langsat Kadap Kecamatan Rao Selatan Kabupaten Pasaman bahwa ia menjelaskan 
tentang sejarah uang siriah ini sudah berlaku semenjak zaman nenek moyang terdahulu. (Sakmar datuak bandaharo, ketua KAN, wawancara pribadi, 03/02/2020 pukul 20.00 WIB)

Dasar diberlakukannya uang siriah ini menurut salah seorang niniak mamak yaitu peraturan adat yang telah disepakati oleh niniak mamak, tokoh adat, dan masyarakat di Nagari Langsat Kadap Kecamatan Rao Selatan Kabupaten Pasaman. Alasan dari diberlakukannya aturan tersebut dengan tujuan agar orang yang akan menikah dengan mengikat dirinya dalam ikatan pertunangan tidak main-main lagi dan melihat keseriusannya untuk menikah atau sebagai bukti awal bahwa mereka akan melangsungkan pernikahan. (Burhan Rajo Nen Adel (adil), wawancara pribadi, 19/02/2020 pukul 10.00 WIB)

Dalam sistem perkawinan adat di Nagari Langsat Kadap Kecamatan Rao Selatan Kabupaten Pasaman ketika seseorang akan melangsungkan perkawinan ada hal-hal dan ketentuan adat yang yang harus dilakukan diantaranya yaitu Monyuruah atau mengantar kata, Timbang Tando dan Qonuri.

Tahapan- tahapan dalam perkawinan di Nagari Langsat Kadap Kecamatan Rao Selatan Kabupaten Pasaman yaitu:

Monyuruah merupakan ketentuan adat di Nagari Langsat Kadap Kecamatan Rao Selatan Kabupaten Pasaman yaitu pihak keluarga laki-laki yang terdiri dari orang tua calon mempelai beserta Niniak Mamak yang melakukan pertemuan di rumah perempuan yang dihadiri oleh calon mempelai dan orang tua mempelai. Pertemuan tersebut merupakan pertemuan awal untuk kedua belah pihak keluarga yang isinya pernyataan maksud dari pihak calon laki-laki untuk mempersunting calon si perempuan. Pada pertemuan itu juga diketahui hasil setuju atau tidak setuju si perempuan. ketika maksud itu diterima dari perempuan. Maka, akan ditentukan hari timbang tando. (Antoni, niniak mamak, wawancara pribadi, 30/12/2019 Pukul 08.00)

Sebelum melangsungkan perkawinan masyarakat melakukan khitbah, masyarakat di Nagari Langsat Kadap Kecamatan Rao Selatan Kabupaten Pasaman menyebutnya dengan Timbang Tando, setiap daerah berbeda-beda dalam melakukan khitbah. Prosesi timbang tando dilakukan pada malam hari yang sudah ditentukan sebelumnya, dimana pihak laki-laki yang terdiri dari laki-laki atau calon, orang tua calon mempelai, datuk beserta niniak mamak bertemu di rumah calon mempelai perempuan pada malam hari untuk melaksanakan timbang tando. Isi dari pertemuan itu adalah pemberian tando berupa kain sarung dari pihak laki-laki dan kain panjang dari pihak perempuan sebagai bukti persetujuan akan dilangsungkan perkawinan. Kedua calon mempelai mengikat janji Dengan istilah adatnya kok duduak indo ke bokisar, kok togak indo ke bopaliang, artinya lah baikek kayu jo tali kok lah boikek janji jo kato. Jadi, maskudnya apabila sudah diadakan pertunangan antara laki-laki dan perempuan maka keduanya sudah terikat dalam pertunangan atau perjanjian. (Antoni, niniak mamak, wawancara pribadi, 30/12/2019 Pukul 08.00)

Dalam pertemuan itu juga diberikan uang siriah (jumlahnya sudah ditentukan oleh adat) oleh pihak laki-laki yaitu sesudah acara tukar menukar antara calon pengantin pria dan calon pengantin wanita. Uang siriah merupakan syarat perkawinan bisa dilangsungkan. Dengan kata lain, apabila uang siriah tidak dibayar maka perkawinan tidak bisa dilangsungkan dan akan mengakibatkan tertundanya perkawinan sampai laki- 
laki sanggup untuk membayarnya, Uang siriah ini sebanyak Rp. 600.000 yang dibuat dalam satu amplot, yang langsung diterima oleh niniak mamak pihak perempuan yaitu tongkunya dan yang membagikan yaitu tongku di Nagari Langsat Kadap Kecamatan Rao Selatan Kabupaten Pasaman dan ini berlaku bagi bujang maupun duda, orang-orang yang akan mendapatkan yaitu niniak mamak, imam qotik, tongku, ketua sumando. Ketentuan adat ini sudah dilakukan semenjak dahulu.

Uang siriah tidak memandang siapapun yang akan melaksanakan perkawinan baik itu bujang maupun duda. Adat pemberian uang siriah dipertahankan keberadaannya oleh masyarakat Nagari Langsat Kadap Kecamatan Rao Selatan Kabupaten Pasaman karena sudah ada semenjak nenek moyang dan sudah melekat sebagai keharusan dalam adat perkawinan nagari Langsat Kadap. (Sakmar datuak bandaharo, ketua KAN, wawancara pribadi /12/2019 pukul 14.00 WIB)

Menurut Sakmar datuak bandaharo bahwa sanksi bagi yang melanggar uang siriah ini yaitu jika pihak laki- laki belum sanggup membayar uang siriah tersebut maka sanksi yag diberikan oleh adat Nagari Langsat Kadap yaitu akan mengakibatkan tertundanya perkawinan sampai laki- laki sanggup untuk membayarnya. (Sakmar datuak bandaharo, ketua KAN, wawancara pribadi /12/2019 pukul 14.00 WIB)

Penulis melakukan wawancara dengan pelaku timbang tando berkenaan dengan uang siriah dan tanda timbang tando yaitu pasangan Didi dan Reka "kami melaksanakan timbang tando seminggu setelah acara monyuruah atau mengantar kata dari pihak laki- laki ketempat pihak perempuan, pada saat timbang tando tersebut saya selaku laki- laki memberikan tanda atau bertukar tanda dengan calon mempelai perempuan yaitu kain sarung dari laki-laki dan kain panjang dari perempuan, namun pada saat proses uang siriah saya belum mampu untuk membayarnya, kami dikenakan sanksi oleh adat yaitu pernikahan kami ditunda sementara, karena ada hal lain saya kemudian tidak jadi menikah dengan calon istri saya tersebut, namun saya menikah dengan perempuan lain. Begitu juga dengan pasangan lainnya yaitu Ivo dan Lisa, sama halnya seperti pasangan Fahri dan Ria, mereka dikenakan sanksi yang sudah ditetapkan oleh adat Nagari Langsat Kadap Kecamatan Rao Selatan Kabupaten Pasaman karena tidak membayar uang siriah kepada niniak mamak pihak perempuan. (D\&R, I\&L, F\&R, Pelaku Timbang Tando, wawancara pribadi, 13/03/2020 pukul 11.00 WIB)

Pasangan Ihsan dan Nita "pada saat pertunangan saya selaku laki- laki memberikan tanda yaitu kain sarung begitu juga dengan perempuan akan memberikan kain sarung. kami bertunangan pada bulan 02 Februari 2019, pada saat timbang tando saya belum mampu membayar uang siriah tersebut, namun pernikahan kami ditunda sementara sampai saya mampu untuk membayarnya, Kemudian saya sanggup membayarnya sampai akhirnya kami menikah. (Ihsan dan Nita, Pelaku Timbang Tando, Wawancara pribadi, pukul 14.00 WIB)

Sebagai adat yang sudah lama dipraktekkan dalam masyarakat di Nagari Langsat Kadap Kecamatan Rao Selatan Kabupaten Pasaman tersebut, adanya uang siriah dalam timbang tando ini sampai sekarang masih dijalankan sesuai dengan aturan adat yang berlaku. Melihat proses pelaksanaan adat tersebut berkaitan dengan yang ditimbulkan akibat dirapkannya uang siriah dalam timbang tando. Menurut niniak mamak di Nagari Langsat Kadap Kecamatan Rao Selatan Kabupaten Pasaman yaitu dampak positif dan 
dampak negatif. (Sakmar datuak bandaharo, ketua KAN, wawancara pribadi, 03/02/2020 pukul 20.00 WIB)

Dampak negatif uang siriah ini kepada masyarakat yaitu jika tidak dibayarkan maka akan diakibatkan perkawinan kedua calon mempelai ditunda sementara, kedua belah pihak akan merasa malu.

Adapun dampak positifnya yaitu di dalam uang siriah ini terkandung nilai tanggung jawab, saling harga menghargai, tegur sapa, masyarakat akan merasa diperdulikan oleh niniak mamak, bagi pihak laki-laki akan menjadi sumando dan akan diikut sertakan dalam musyawarah apapun yang ada di Nagari Langsat Kadap Kecamatan Rao Selatan Kabupaten Pasaman. Uang siriah ini menjadi syarat dalam perkawinan dan ini sudah menjadi ketentuan adat yang harus dipatuhi. Hal ini sesuai dengan pendapat bapak Sakmar datuak bandaharo selaku ketua KAN, hal yang serupa juga disampaikan dengan bapak Antoni selaku niniak mamak dan tidak berbeda juga disampaikan dengan bapak Burhan selaku Rajo nen adel di Nagari Langsat Kadap Kecamatan Rao Selatan Kabupaten Pasaman. (Burhan Rajo Nen Adel (adil), wawancara pribadi, 19/02/2020 pukul 10.00 WIB)

Dari uraian diatas penulis menarik kesimpulan bahwa pemberian uang siriah diberikan oleh pihak keluarga laki-laki kepada niniak mamak pihak keluarga perempuan sebesar Rp. 600.000 dalam timbang tando selain mahar.

Tujuan diberlakukannya uang siriah dalam timbang tando yaitu Adanya sebuah aturan tentunya mempunyai maksud dan tujuannya tersendiri, aturan uang siriah ini diberlakukan bagi siapa saja yang mau melaksanakan pernikahan di Nagari Langsat Kadap. Pemberlakuan aturan ini sudah sangat lama yaitu pada zaman nenek moyang terdahulu dan sudah menjadi rutinitas bagi laki- laki dan perempuan yang ingin melaksanakan perkawinan. Adapun tujuan diberlakukannya uang siriah dalam timbang tando yaitu sebagai berikut Untuk melihat keseriusan dari laki- laki, Adanya sebuah perkawinan tentu harus ada niat yang baik, Bahwa dalam pernikahan perlu adanya keseriusan dan tidak main- main dalam melaksanakan pernikahan. Terjalinnya silaturahmi antara calon peminang dengan niniak mamak, Sebuah perkawinan tentunya membutuhkan bantuan dari tokoh- tokoh adat contohnya niniak mamak, ia berperan penting mulai dari awal sampai akhir proses pernikahan, disana niniak mamak juga memberikan nasehat- nasehat supaya siap untuk menjalani rumah tangga. Memperlihatkan rasa tanggung jawab sebagai laki- laki, Dalam sebuah perkawinan tentunya harus mempunyai niat dan rasa sungguh- sungguh ingin menjalankan rumh tangga yang baik dan tentram serta rumah tangga yang berkah. Dengan diberlakukan uang siriah ini maka akan kelihatan serius untuk menikahi perempuan yang dipinangnya, rasa tanggung jawabnya untuk melaksanakan rumah tangga dengan perempuan yang telah dipinangnya, dan tidak diragukan lagi mencari nafkah untuk anak dan istrinya. (Burhan rajo nen adel (adil), wawancara pribadi, 02/03/2020 pukul 10.00 WIB)

Pelaksanaan uang siriah merupakan adat kebiasaan yang turun- temurun di Nagari Langsat Kadap Kecamatan Rao Selatan Kabupaten Pasaman. Dilihat dari segi hukum Islam persyaratan 'urf yaitu: 'Urf itu mengandung kemaslahatan dan dapat diterima akal sehat, Uang siriah ini dilakukan pada umum masyarakat dan mempunyai kemaslahatan yaitu: terjalinnya silaturahmi, memperlihat rasa tanggung jawab sebagai laki- laki, untuk 
melihat keseriusan dari pihak laki- laki. 'Urf tersebut berlaku umum pada masyarakat yang terkait dengan lingkungan 'urf atau dikalangan sebagian besar masyarakat, Uang siriah ini berlaku pada seluruh masyarakat di Nagari Langsat Kadap Kecamatan Rao Selatan Kabupaten Pasaman dan bagi yang melanggar adanya aturan uang siriah ini maka dikenakan sanksi yaitu terjadinya penundaan perkawinan. 'Urf yang dijadikan dasar bagi penetapan suatu hukum telah berlaku pada saat itu, bukan 'urf yang muncul kemudian, Uang siriah ini sudah berlaku turun- temurun yaitu semenjak zaman nenek moyang terdahulu. 'urf tidak bertentangan dengan dalil syara' yang ada atau bertentangan dengan prinsip yang pasti, Uang siriah ini tidak ada dalil yang melanggar dan tidak ada dalil yang mengaturnya, ini dilakukan dalam rangka khitbah dan khitbah tidak ditentukan bagaimana prosesinya dalam hukum Islam.

Mengenai pelaksanaan pembayaran uang siriah ini menurut analisis penulis, di samping termasuk kepada 'urf shahih, mengandung unsur positif dan negatif dari tradisi tersebut. Adapun unsur positif tersebut adalah: masyarakat menghargai adanya keberadaan dari niniak mamak setempat, karena peran niniak mamak dalam perkawinan sangatlah penting. Bagi pihak laki-laki akan dihargai dan dianggap sebagai sumando di masyarakat kampung setempat, untuk memperlihat keseriusan menikah bagi pihak lakilaki, memperlihatkan tanggung jawabnya, Masyarakat juga merasa tertolong dengan bantuan dari niniak mamak mulai dari proses awal sampai dengan akhir pernikahan tersebut, Terjalinnya silaturahmi antara niniak mamak yang baik, dan niniak mamak akan memberikan nasehat keapada calon pengantin supaya siap untuk menjalankan rumah tangga, Akan mendapatkan ketenangan bathin karena telah melaksanakan perintah dari nenek moyang dahulu.

Adapun unsur negatif apabila uang siriah di Nagari Langsat Kadap Kecamatan Rao Selatan Kabupaten Pasaman tidak dibayarkan diantaranya yaitu: Diakibatkan tertundanya suatu perkawinan, Dapat membuat nama baik keluarga masing- masing pihak menjadi tercoreng dimasyarakat, Adat boleh dilakukan selama tidak ada dalil yang larangannya sama sekali dari agama. Ini menunjukkan bahwasanya syariat Islam ini mencakup semua perbuatan hambanya dan perbuatan tersebut ada hukum-hukumnya, dan bukanlah syariat Islam ini hanya khusus berputar di mesjid dan hanya membahas masalah ibadah saja, akan tetapi sariat Islam ini mencakup semua perbuatan hambanya baik hal itu adat kebiasaan maupun masalah ibadah, dan itu merupakan keutamaan yang Allah limpahkan kepada kita dengan syariatnya.

Maksud dari uang siriah di Nagari Langsat Kadap Kecamatan Rao Selatan Kabupaten Pasaman yaitu pemberian calon suami berupa uang kepada niniak mamak pihak perempuan sebagai bentuk penyerahan atau diterima anak keponakan oleh ibu bapak, sanak saudara, dan niniak mamak. Uang siriah ini gunanya untuk dibagi-bagikan kepada mamak-mamak, datuak, tongku, imam qotik, dan ketua sumando. Pemberian uang siriah di Nagari Langsat Kadap Kecamatan Rao Selatan Kabupaten Pasaman sangat diperlukan, karena masyarakat mengangap adanya nilai-nilai kebaikan dan kemaslahatan, terkandung nilai tanggung jawab, keseriusan untuk menikah, saling harga menghargai, tegur sapa, masyarakat akan merasa diperdulikan oleh niniak mamak, bagi pihak laki-laki 
akan menjadi sumando dan akan diikut sertakan dalam musyawarah apapun yang ada di Nagari Langsat Kadap Kecamatan Rao Selatan Kabupaten Pasaman.

Pelaksanaan Pemberian uang siriah dalam perkawinan di Nagari Langsat Kadap telah ada sejak dahulu dan dilakukan secara berulang- ulang dan masih dilaksanakan hingga sekarang. Adat ini diberlakukan untuk melihat keseriusan dari pihak laki- laki untuk menikahi perempuan yang dipinangnya, masyarakat menghormati adanya niniak mamak, karena dalam Minangkabau peran niniak mamak sangat penting. Apabila fenomena tersebut dikaitkan dengan hukum Islam maka fenomena adat tersebut tidak terlepas dari 'urf. Adat kebiasaan yang sudah mendarah daging dalam kehidupan masyarakat di Nagari Langsat Kadap Kecamatan Rao Selatan Kabupaten Pasaman. Kaidah fikih yang berkaitan dengan adat dan kebiasaan ini adalah:

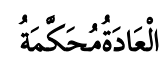

"adat kebiasaan dapat ditetapkan sebagai hukum"

Pelaksanaan pemberian uang siriah ini sesuai dengan syarat 'urf shahih karena kebiasaan yang dilakukan oleh masyarakat Nagari Langsat Kadap ini telah ada sejak dahulu dan dilakukan secara berulang-ulang, disukai oleh orang banyak dan kebiasaan tersebut sudah populer dan dikenal oleh banyak komunitas.

“segala bentuk yang sudah menjadi kebiasaan oleh manusia merupakan alasan yang harus dilaksanakan"

Berdasarkan kaidah fikih di atas dapat penulis analisa bahwa suatu kejadian yang terjadi secara berulang-ulang yang dilakukan secara terus- menerus dan sudah ditetapkan yuridisnya oleh masyarakat atas dasar keputusan orang-orang terdahulu. Maka adat tersebut bersifat mengikat bagi masyarakat setempat.

Menurut analisis penulis bahwa pelaku timbang tando yang tidak membayar uang siriah ada beberapa orang. Namun penulis mewawancarai 3 orang yang tidak membayar uang siriah dan ada satu orang yang membayar uang siriah. Tiga orang yang tidak membayar uang siriah berakibat tertundanya perkawinannya dan orang yang membayar uang siriah dapat melanjutkan perkawinannya.

Menurut analisa penulis bahwa pemberian uang siriah dari pihak laki- laki kepada niniak mamak pihak perempuan adalah termasuk kepada golongan ' urf shahih. Pada masyarakat di Nagari Langsat Kadap Kecamatan Rao Selatan Kabupaten Pasaman sampai sekarang ini masih sangat mempertahankan sanksi bagi orang yang tidak membayar uang siriah. Sanksi ini tentu mempunyai tujuan yaitu memberi efek jera terhadap masyarakat supaya tidak mudah untuk membatalkan perkawinan karena tidak membayar uang siriah.

Pengunduran perkawinan atau perkawinan ditunda sementara merupakan hak masing- masing yang tadinya telah mengikat perjanjian dalam monyuruah (melamar), Islam tidak menjatuhkan hukuman materil, sekalipun perbuatan tersebut dipandang tercela oleh sebagian orang. Mengenai sanksi tersebut, ajaran Islam tidak mengatur secara khusus, tetapi kebiasaan (adat) yang berlaku di dalam kehidupan masyarakat, selagi tidak bertentangan dengan ajaran Islam adat tersebut diperbolehkan. Kedudukan hukum adat ('urf) dalam fiqh Islam, diperbolehkan yang sifatnya Shahih atau al'adah ashahihah yaitu, 'urf yang tidak bertentangan dengan syari'at. 
Sanksi adat adalah sanksi yang dijatuhkan berdasarkan kesepakatan sekelompok masyarakat lembaga adat kepada orang yang melanggar adat dengan cara musyawarah sesuai dengan adat salingka Nagari.

Jadi dapat dipahami bahwa pemberian sanksi jika uang siriah tidak dibayarkan pada Perkawinan adat di Nagari Langsat Kadap Kecamatan Rao Selatan Kabupaten Pasaman adalah merupakan aturan adat yang sudah dilaksanakan secara turun-temurun yang terus dijaga dan dipandang baik oleh seluruh masyarakat yang ada pada masyarakat di Nagari Langsat Kadap Kecamatan Rao Selatan Kabupaten Pasaman. Bertujuan agar masyarakat tidak mudah membatalkan sebuah hubungan, untuk menjalankan aturan adat, sebagai pelajaran dan agar tidak mengingkari janji yang telah dibuat bersama.'urf yang terdapat pada sanksi pembatalan perkawinan adalah 'urf shahih karena telah memenuhi syarat-syarat dijadikannya 'urf sebagai landasan hukum.

\section{KESIMPULAN}

Pelaksanaan uang siriah dalam pertunangan pada masyarakat Nagari Langsat Kadap pertama diawali proses monyuruah (menyampaikan kehendak). Kedua, proses timbang tando, setelah acara tukar menukar selesai maka dilanjutkan pemberian uang siriah oleh pihak laki- laki kepada niniak mamak perempuan berjumlah Rp. 600. 000. Sanksi bagi yang melanggar diakibatkan terjadi penundaan perkawinan yang sudah ditetapkan oleh kesepakatan bersama niniak mamak di Nagari Langsat Kadap.

Tinjauan 'urf terhadap keberadaan uang siriah dalam timbang tando adalah termasuk kepada golongan 'Urf Shahih, hal ini berdasarkan syarat-syarat 'Urf dijadikan sebagai sumber hukum Islam yaitu, adat tersebut bernilai maslahat karena berdampak baik kepada pihak keluarga laki-laki dan pihak keluarga perempuan. Dengan adanya uang siriah ini memperlihatkan keseriusan seorang laki-laki menikahi seorang perempuan, memperlihatkan tanggung jawab laki-laki, terjailnnya silaturahmi dengan niniak mamak. Bagi keluarga yang keberatan atau tidak mampu seharusnya ditanggung bersama oleh niniak mamak pihak laki-laki sebagai ta'aun atau tolong menolong dalam Q.S. An- Nisaa: 2, supaya tidak mendapat sanksi dan penundaan perkawinan.

\section{REFERENSI}

Asmawi. 2013. Perbandingan Ushul Fiqh. Jakarta: AMZAH

Dahlan Rahman, 2014. Ushul Figh. Jakarta: Amzah

Djalil Basiq, 2010. Ilmu Ushul Figh (Satu dan Dua). Jakarta: Kencana

Effendi, Satria. M. Zain. 2005. Ushul Fiqih. Jakarta: Kencana.

Elimartati, Nailurrahmi. 2013. Fiqih Integrasi IPA. Batusangkar : STAIN Batusangkar Press

Firdaus, 2017. Ushul Figh: Metode Mengaji dan Memahami Hukum Islam. Depok: PT Raja Grafindo Persada

Hadikusuma, Hilman. 2003. Hukum Waris Adat. Bandung: Citra Aditya Bakti 
Ibrahim. 2018, Tatanan Adat Warisan nenek moyang orang minangkabau, Kristal Multimedia :Bukittinggi.

Mardefi Rismi, 2019. Problematika perkawinan malakok suku menurut perspektif figh, Skripsi, Institiu Agama Islam Negeri Batusangkar.

Mufid Moh, 2016. Ushul Figh Ekonomi dan Keuangan Kontemporer. Jakarta: Kencana

Muhammad, Bushar. 2002. Asas-Asas Hukum Adat. Jakarta: PT. Pradnya Paramita

Nuruddin, Amiur dan Azhari Akmal Tarigan. 2004. Hukum Perdata Islam di Indonesia. Jakarta: Kencana.

Syarifuddin Amir, 2008. Ushul Fiqh. Jilid 2. Jakarta: Kencana

Syarifuddin, Amir. 1984, Pelaksanaan hukum kewarisan Islam dalam Lingkungan Adat Minang Kabau. Jakarta: Gunung Agung

Wulandari Yosi, 2017. Tradisi Ulu Minyak di Nagari Batipuah Baruah Tanah Datar Menurut Hukum Islam, Skripsi, Institut Agama Islam Negeri Batusangkar.

Wiranata, I Gede. 2005. Hukum Adat Indonesia. Bandung: P.T. Citra Aditya Bakti

Yulia. 2016. Buku Ajar Hukum Adat. Sulawesi: Unimal Press

Yaswirman. 2006. Hukum Keluarga Adat dan Islam. Padang: Andalas University Press 